\title{
Christianity and Environmental Care in Nigeria: The Role of Christians in Addressing Indiscriminate Refuse Disposal
}

\author{
John Arierhi Ottuh \\ Obong University, Nigeria \\ E-mail: wibachef90@gmail.com \\ Doi: https://doi.org/10.46222/pharosjot.103.015
}

\begin{abstract}
Scholars in the field of theology and biblical studies have extensively explored eco-theology from Genesis creation narratives especially $1: 26$ and 28 . In spite of the good numbers of literature in this field of study, less is known in the area of contextual eco-theology that focuses on Christians and environmental care in Uvwie, Nigeria. Therefore, using the eco-theology approach in the interpretation of Genesis 2:15, this paper examines the importance of Christians' involvement in environmental care by using Uvwie Local Government Area of Nigeria as a focus point. Drawing on

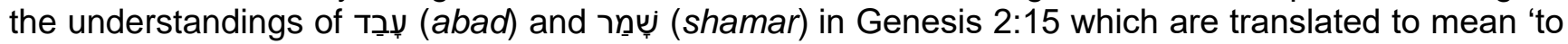

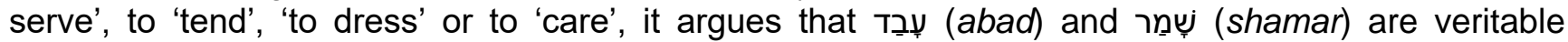
Biblical and theological bases for Christian involvement in environmental care in contemporary society such as Uvwie. It shows that Genesis 2:15 implies environmental stewardship and environmental conservation and as such a theological basis for Christians in Uvwie-land to develop a positive attitude towards the community and its environment and desist from dumping refuse indiscriminately in the community. As such this paper contributes to the discourse on climate issues in Africa. Besides, humanities scholars will appreciate the essentiality of Christians' contribution to a sustainable clean and green environment by becoming custodians of God's creation.
\end{abstract}

Keywords: Eco-theology, Christianity, environmental care, Uvwie Local Government area, refuse disposal.

\section{Introduction}

Climate change has become a global discussion in recent times especially in United Nations' meetings. It has been ascertained that human activities in the environment grossly impact climate change (Mahmoud \& Gan, 2018: 1329; Paeth, 2008). The issues of environment and climate change have also attracted discussion in academia, including departments of Biblical/Theological studies. In Theological studies, it is called echo-theology. For instance, in the graduate programme of the University of Notre Dame's Department of Theology, Eco-Theology is being offered as a course. In recent times, eco-theology is gaining ground in Biblical and theological debates. For instance, DeaneDrummond (2008); Pihkala (2016); Darragh (2000); Torretta (2015); Waqainabete (2018:1-28); and others too numerous to mention here, have extensively discussed the theme of eco-theology. In spit of this, less is known in the area of contextual eco-theology that focuses on Christians and environmental care in Uvwie, Nigeria.

Coming down to Africa, especially in Nigeria, the discussion on environmental protection has also attracted scholarship with a lot of attention focussing on environmental protection. It is so because 
Nigeria as a nation has become more at alert to the issues after the incidence of the flood disasters that took place especially between 2011 and 2014 leading to loss of human lives, huge socioeconomic losses (worth over US\$9.5 billion), and environmental impacts capable of threat to food security (Jatto \& Stanislas, 2017:118; Adekola \& Lamond, 2018: 1145; Ottuh, 2018:69; Echendu, 2020). It has also been agreed among scholars in Nigeria that human activities against the environment are grossly responsible for the monumental flood the nation experienced in 2011 and 2012 (Ottuh, 2018:69). One of the major problems apart from the rise of water levels from the rivers that affected coastal areas and collapse of drainages, blockage of drainages by refuse was responsible for the flood disaster. The blockage was a result of indiscriminate refuse disposals into drainages or other water channels by residents. While we agree with scholars that climate change, poor urban planning practices, and inadequate environmental infrastructure are responsible for the flooding in Nigeria (Aja \& Olaore 2014; Agbonkhese et al. 2014; Satterthwaite 2017; Echendu, 2020:1-2), we also discovered from personal observations that indiscriminate refuse disposal into drainages in Uvwie community is highly responsible for flooding in Uvwie. While government environmental infrastructure can be seen as inadequate in the Uvwie community, the proper utilisation of the existing drainage system can be helpful in reducing flooding in the Effurun metropolis. Apart from the severe flooding in 2011 and 2012 across Nigeria, Uvwie's case is becoming a 'recurring decimal' in the sense that during rainy seasons, especially when there is a heavy downpour, there is usually flooding in many parts of the community such as Effurun and Ekpan every other year. From personal experience and as eye witnesses of the situation, we discovered that refuse dumps on drainage and on unauthorized sites are mostly responsible for the blockage of the available drainage system.

Previously, scholars have contributed to the issue of impacts of flooding in Warri South Local Government Area (Aderoju et al 2014); impact of petroleum activities on the socio-economic life of the Uvwie people (Basil \& Osheyen, 2015); and vulnerability and adaptation to flooding in Uvwie Local Government Area (Olajire, 2016). This present paper intends to contribute to eco-theology from the perspective of Uvwie Local Government Area of Delta State, Nigeria as regards Christians' involvement in environmental care issues Using an eco-theology approach by drawing from the

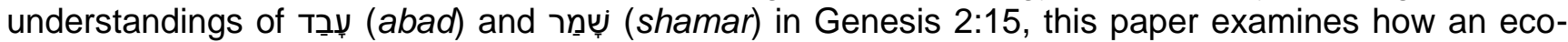
theology can be constructed for the Church in Uvwie community, Nigeria as regards Christians' involvement in environmental care. Drawing on the understandings of (abad) and (shamar) in Genesis 2:15 which are translated to mean 'to serve', to 'tend', 'to dress' or to 'care', it argues that עָבָבָ (abad) and (shamar) are veritable Biblical and theological bases for Christian involvement in environmental care in contemporary society such as Uvwie. Since we are now aware that human activities against the environment have become part of the causes of flooding and environmental pollution, it is therefore obvious that a human solution is inevitable and sorely needed. Since a human solution is important, which theological agenda can be explored to inculcate the idea of environmental care on the Church among the Uvwie people of Nigeria? And in what way can Christians in the Uviwe community contribute to environmental care in the community?

\section{Description of the Setting: Uvwie Local Government Area}

What follows now is a birds-eye view description of Uvwie Local Government Area in terms of location, population, economy and Christianity. Uvwie Local Government Area (ULGA) with its headquarter in Effurun, is located in Delta State in South-South geopolitical zone of Nigeria. It is "located on lat.5.15 ${ }^{\mathrm{ON}}$ and $6^{\mathrm{ON}}$ and long $5.40^{\circ \mathrm{E}}$ and its geographical coordinates are $0945^{0 \mathrm{~N}}$ and 0853 ${ }^{\circ \mathrm{E}}$ (Basil \& Osheyen, 2015:1319). It is bounded by Okpe Kingdom in the North and Udu and 
Ughievwen in the North-West, Agbarho kingdom in the North East, Agbarho-Ame in the East, Okere Urhobo kingdom in the South and Itsekiri in the South West. Uvwie is one of the Urhobo kingdoms in Delta Central. Apart from Warri, Effurun is the next busiest, industrial and highly commercial city in the state, amounting to $60 \%$ of the companies that are operating in the Warri axis (Duke \& Albert, 2007:332). The biggest city of Uvwie is its capital Effurun. Effurun is sharing a common boundary with Warri. Population wise, according to the National Population Commission (NPC, 2006), Uvwie Local Government Area has a total population of about $188,728^{1}$ amounting to $0.13 \%$ of the population of Nigeria in 2006 which stood at 140,431,790. The total geographical area of the local Government is 95.157 sq km with a population density of about 1524 (Duke \& Albert, 2007:332).

The climate of the area is of the monsoon type, with two seasons; namely, a wet season spanning from March to October and the dry season covering late October to February. Each of these seasons is characterized by the influence of the South Westerly wind from the equatorial rain belt (NIMET, 2013; Kassali, Girei \& Sanu, 2018:171). Uvwie LGA spreads across the city of Effurun and other adjoining communities such as Alegbor, Ebrumede, Chaguolo, Ekpan, Ogbomro, Ohore (II), Okoribi, Ugboroke, Ugborikoko, and Ugbolokposo. The main economic mainstay of the people involves farming (crops and fish farming), transportation business, trading, civil service and oil business by multinationals such as Chevron and other indigenous oil firms.

The community has a market popularly known as Effurun market. This market generates a lot of refuse due to its size. Although, smaller markets also known as "small markets" are established within the city for contiguous and access reasons, the main market functions daily but mainly once a week. For instance, there are small markets in Jakpa, Airport, PTI, and Refinery Roads. These markets function on a daily basis while the big market (Effurun market) functions mainly weekly. In each of these commodity markets, perishables are highly traded. These markets usually generate a lot of refuse which some deviants dump on the road's pavements or drainages.

Concerning Christianity in Uvwie-land, many Church denominations have been established. These Church denominations range from Mainline Churches (Roman Catholic, Baptist, Anglican, Methodist, Presbyterian, Qua Iboe, etc) to African Initiated Churches such as Word of Life Bible Church, Rainbow Christian Assembly, Holy Ghost Dominion, Church of God Mission, and others too numerous to mention here. In the Christian Association of Nigerian-Uvwie chapter, the five denominational blocs that make up the association are visible. They are the Christian Council of Nigeria (CCN), Catholic Secretariat of Nigeria (CSN), Christian Pentecostal Fellowship of Nigeria (CPFN)/Pentecostal Fellowship of Nigeria (PFN), Organization of African Instituted Churches (OAIC), and TEKAN and ECWA Fellowship.

We find it difficult, to give the statistics of Christianity in Uvwie because such statistics have not been embarked upon. However, from the population of Christians in Uvwie especially from Church buildings or worship centres across the local government, we assume that Christians are in a very

\footnotetext{
${ }^{1}$ After the 2006 population census, the Uvwie Local Government Area of Delta State took the National Population Commission of Nigeria to the Census Tribunal of Nigeria at Abuja for not giving a true reflection of Uvwie's population. This case was won by the Uvwie people because the official figures on NPC record $(188,728)$ do not reflect the real population of the Uvwie people of Nigeria. This made the Tribunal to rule that the complaint of the people be noted and that the area be remapped and recounted in order to have a true figure of the population of Uvwie Local Government Area. For evidence, see the Census Tribunal "A" of Nigeria Holden at Abuja with Complaint No. CTA/DELTA/02/22. The judgment was delivered on May 30, 2013.
} 
large number may be up to $85 \%$ of the entire population. Apart from Christianity, Islam, and other sects such as Jehovah's Witness, Mormonism, etc, are also on the ground.

\section{Approach: Eco-Theology}

In this study, we explore the echo-theology approach to inculcate the idea of environmental care on the Church among the Uvwie people of Nigeria. We did this by first of all by showing the evidence of indiscriminate dumping of refuse on drainages and unauthorised sites by using pictorial evidence and secondly, by exploring scriptural criticism. We then contextualised eco-theology in Uvwie community. By so doing, we discussed the issues especially in the light of the Genesis tradition of caring for the environment. Apart from existing literature, we went round the entire Local Government Council area with a digital camera to take photographs of refuse blocking drainages. Using the eco-theology approach here, we discuss the issue with pictorial imagery (on the spot assessment). In my understanding, eco-theology as the name implies simply means a theological approach that puts the ecosystem at the centre of discussion and interpretation by using the Bible and theological thoughts to liberate the ecosystem from human and industrial abuse. The reason for this theological enterprise is precipitated on the belief that the earth is the home of all living things and that God created all living things, non-living things and the environment they reside in. As such, both living things and their environment should be treated with the care and preservation they deserve. As such, eco-theology is concerned with existing environmental problems within local and global spheres with the purpose of contributing spiritual and physical solutions to such problems. In this case, we discuss the environmental issue confronting Uvwie community in Nigeria and proffer Christian participation in environmental care.

Historically, "Christian ecotheology emerged as a scholarly discourse in the 1970s, partly in response to growing ecological concerns, expressed for example in the contested report to the Club of Rome on Limits to growth [1972]" (Conradie, 2020:1).Since then scholars have taken it up as a field of scholarly discussion by making greater clarifications on it. According to Celia Deane-Drummond, ecotheology "is that reflection on different facets of theology in as much as they take their bearings from cultural concerns about the environment and humanity's relationship with the natural world" (DeaneDrummond, 2008:x).Broadly speaking, it is "a particular expression of contextual theology that emerges in the particular contemporary context of environmental awareness that has characterised the late twentieth and early twenty-first centuries" (Deane-Drummond, 2008:x). In a nutshell, DeaneDrummond explains further that "...eco-theology seeks to uncover the theological basis for a proper relationship between God, humanity, and the entire cosmos". Humans are thus understood in Christian tradition to be created, but they are inclined to be alienated from the natural world through their own propensities towards dominion (Deane-Drummond, 2008:xii). Eco-theology is therefore, an attempt to recover human sense of place on the earth in order to remind humans including Christians of the understanding of the earth as a common home inhabited with other creatures of God.

Apart from Celia Deane-Drummond, other scholars have used the eco-theology approach in their researches. For example, Neil Darragh examines "the impact of ecotheology on traditional concepts and perspectives [and shows] implications of three significant Ecotheological concepts, namely, intrinsic value, connectedness, and sustainability" (Darragh, 2000:160). Also, Sigurd Bergmann has contributed using the eco-theology approach by looking at nature and creation from the perspectives of Abrahamic and classical Christianity (Bergmann, 2013). Also, Lawrence Troster has used the ecotheology approach from the perspective of giving it a contemporary definition (Troster, 2013). Another scholar, Christopher Hrynkow shows how ecotheologians, argue for the importance of seeing the 
Trinity in the light of a green world (Hrynkow, 2017). Also, Hans Heimbrock and Jörg Persch have contributed immensely to this approach in their new edited book in which a lot of sub-themes on ecotheology were discussed from various perspectives such as philosophy, religion, theology, etc. (Heimbrock and Persch, 2021). The literature on eco-theology goes far beyond the ones we have mentioned here. However, all of these give a clue to what we are expected to do in this paper in terms of approach. We, therefore, explore the echo-theology approach to give a direction based on existing biblical knowledge on environmental care and how it concerns Christians in Uvwie, Nigeria. In order to achieve this, we explore the Garden of Eden (GE) environmental model to inculcate the idea of environmental care in the Church among the Uvwie people of Nigeria.

\section{Indiscriminate Refuse Disposal in Uvwie Community: Pictorial Evidence}

Here, we show pictorial evidences of indiscriminate refuse dump in Uvwie Local Government Area. This evidence is intended to indicate various points where such act is taken place in Uvwie Local Government Area. This was carried out by taking a tour around the area with a camera. Various sports where refuses were indiscriminately dumped on drainages in those areas were snapped. The snapped shots are shown in figures 1.1-3.3 below.

Fig 1: Refuse blocking Drainages in Effurun and Ekpan

Fig 1.1: Refuse in PTI Road Drainage

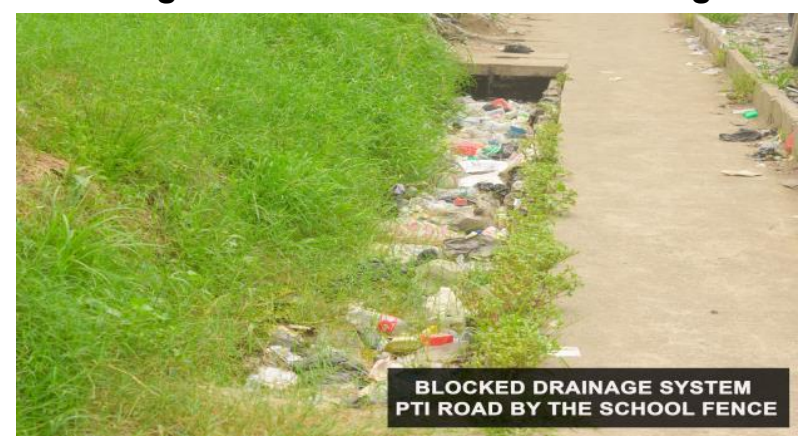

Fig 1.2: Refuse in Aka Avenue Drainage

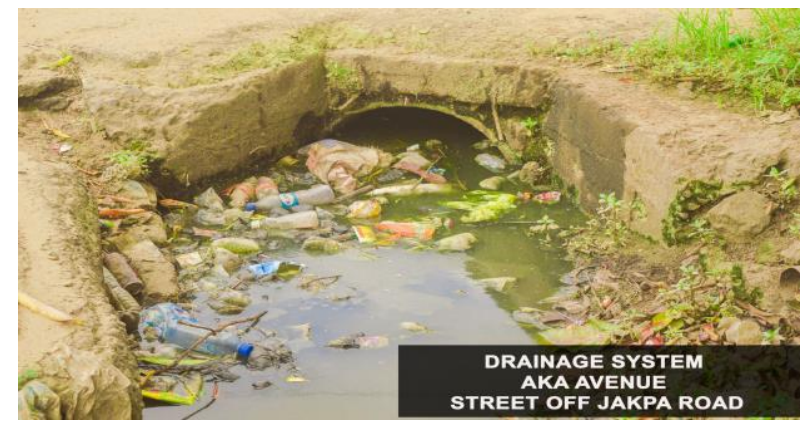

Fig 1.3: Refuse at Ekpan Expressway near flyover

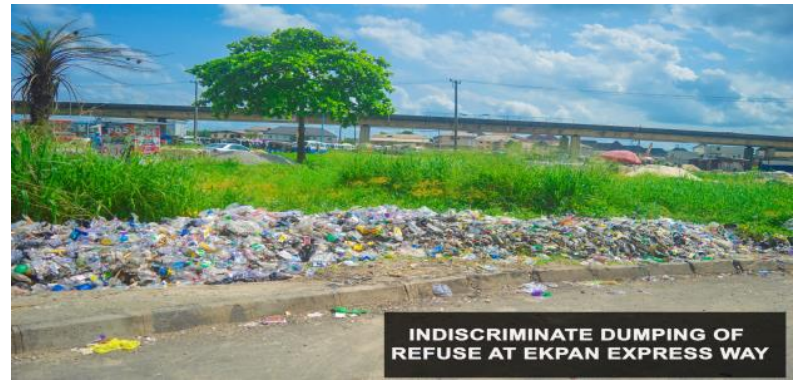


Fig 2: Refuse blocking Drainages in Ugbomro and Ugbolokposo

Fig. 2.1: Refuse in Ugbomro Drainage

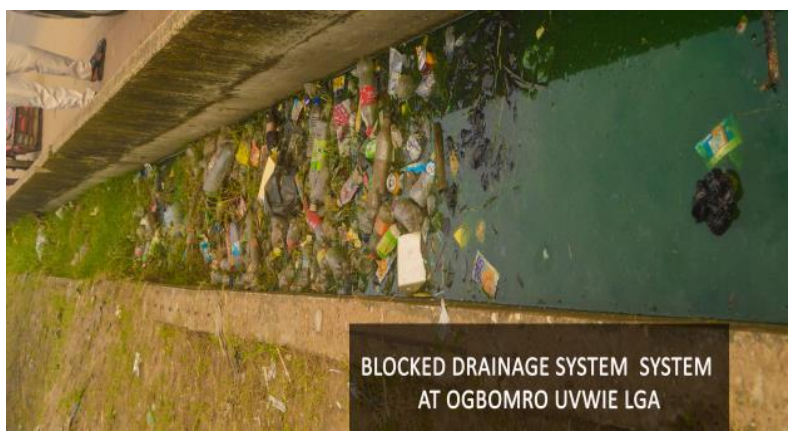

Fig. 2.2: Refuse in Ugbolokposo Drainage

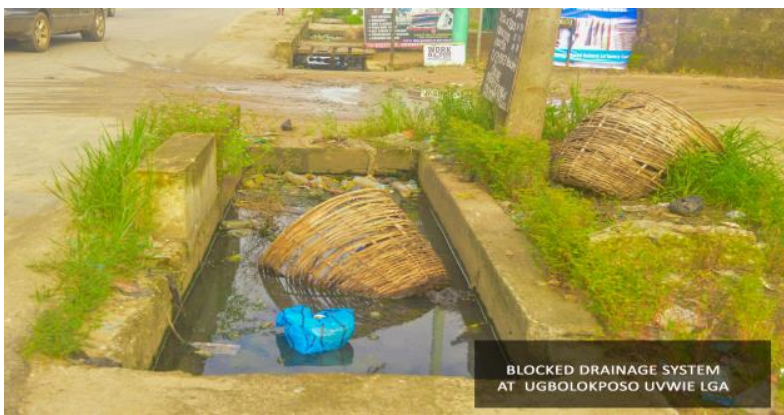

Fig. 2.3: Refuse in Ugbolokposo Drainage

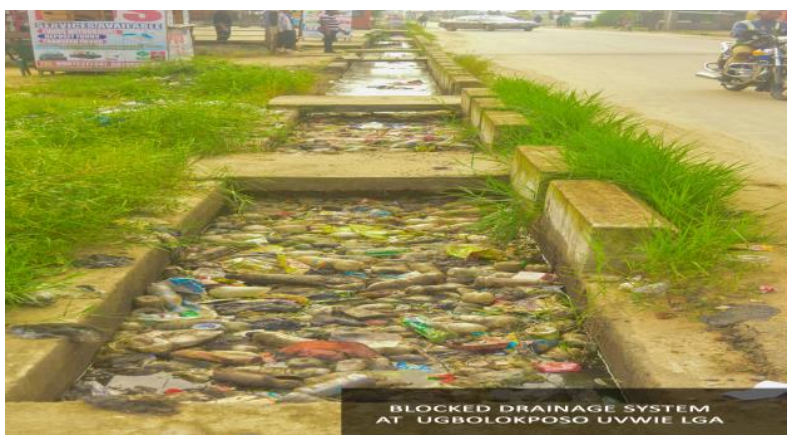


Fig. 3: Refuse blocking Drainages in Ugboroke and Ugborikoko

Fig. 3.1: Refuse in Ugboroke Drainage

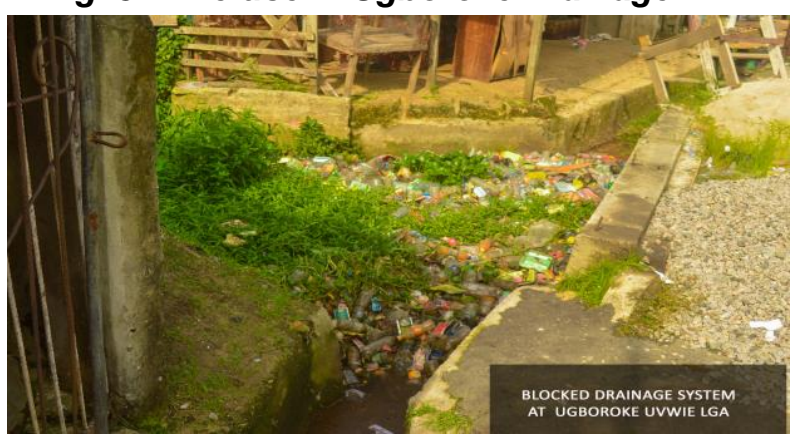

Fig. 3.2: Refuse in Ugborikoko Drainage

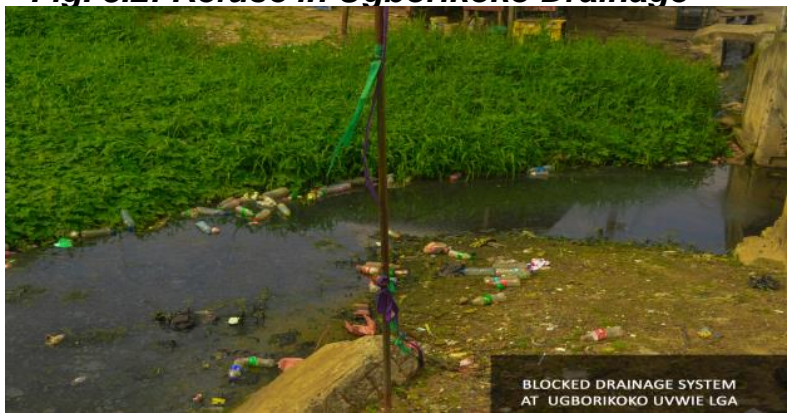

Fig. 3.3: Refuse in Ugborikoko Drainage

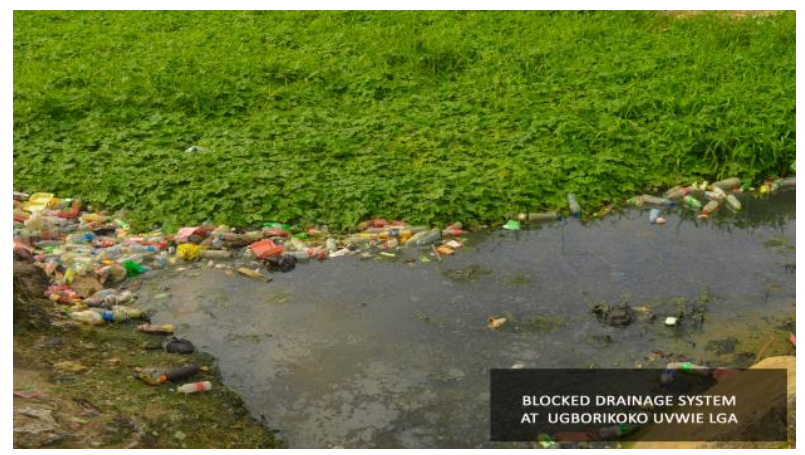

In the above pictorial representations, Effurun and some major sub-communities (Ekpan, Ogbomro, Ugbolokposo, Ugboroke, and Ugberikoko) were reached. Most of the refuse seen on the surface are used cans, empty cartons, raffia baskets, and wastewater sachets popularly known as bottled/pure water sachets. These materials hardly decay and when they do, take a very long time to do so. Apart from these materials, there is other refuse (such as used clothes and other domestic wastes) in the drainage that cannot be captured by the camera because they are submerged under the remnant water. These kinds of refuse submerged under the remnant water gradually cover the drainage from bottom to up. When this happens, water is unable to flow freely during a heavy downpour of rain thereby causing a flood in many parts of the community each time it rains. 
Usually, when rain falls, the refuse is pushed by the water current from one end to another making the refuse concentrate more at the other end. We took the photograph of such areas which are being represented here in figures 1.1-3.3. These eventually block the drainage as shown above. Apart from indiscriminate refuse disposal on water channels/drainage in Uvwie community, developers of properties also contribute to the blockage of water channels. They do this by storing materials such as granite, sand, and rods across existing drainage on existing roads thereby completely covering the drainage for as long as the construction lasts. Also, some build houses on water channels due to a lack of proper town planning on the part of the government. While this present paper does not cover details on this latter aspect, it is worth noting for further research / investigation.

\section{Exploring the Biblical text (Genesis 2:15)}

One of the exponents of eco-theology, Lynn White in her thesis, opines that Christianity is a root cause of the environmental crisis especially given its deeply anthropocentric orientation (White, 1967; Conradie, 2020:1). Drawing from Genesis 1:28, White seems to have a problem with the Hebrew

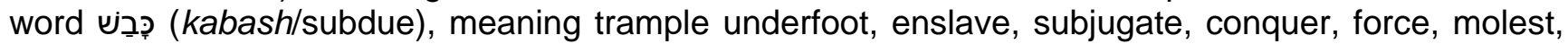
overcome, or bring under control. A similar word is רָ (radah/dominion), meaning rule, govern, reign, officiate, or trample grapes. As such, White (1967) argued that within the Western Christian theology, "nature has no reason for existence save to serve (humans)." For White, this formed the basis for which Christianity (ancient and modern) in creating and supporting the developed world's increasingly successful control of the natural world through technology. This is why eco-theology is partly a response to Lynn White's thesis. So many scholars have followed or critiqued White on her interpretation of Genesis as the cause of environmental subjugation. One of those supporting White in recent times is Peet Van Dyk of the University of South Africa. Just like White, Dyk (2015) sees in

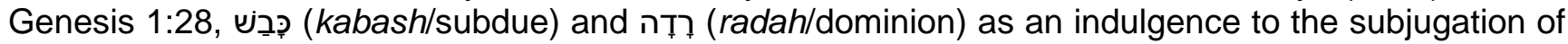
the environment by humans (Dyk, 2015:524). For Dyk, the use of responsible stewardship in Genesis 2:15 is a kind of assuage for Genesis 1:28.

One of those who critiqued White in recent times is Gregory Hitzhusen. Hitzhusen $(2019)^{2}$ says that "most of the commentary that pegs the Bible as anti-environmental, including White's thesis, attends to just a couple of passages in Genesis as if those few lines suffice to judge a whole tradition." For Hitzhusen, this kind of submission can lead to persuasive claims, especially for less theologically informed readers. Hitzhusen thinks that White did not put into consideration the textual context of the Genesis tradition, hence his fraudulent conclusion that Genesis is the root cause of environmental crises in the world. On a more serious note, Hitzhusen advises that scholars should always seek to know the context of a verse within a chapter. It is on this note, I explore Genesis 2:15 for this particular paper by resting on Christian tradition on the text.

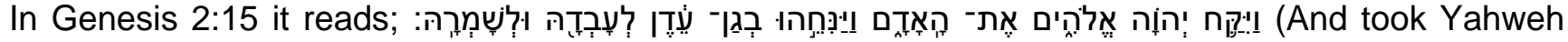
God the man, and put him in the garden of Eden to tend and keep it). In smooth English, the text can read thus: "And the Lord God took the man and put him in the Garden of Eden to tend and keep it." In this text, two verbs convey the understanding of environmental care. The first verb that conveys the message of care in the text iv עִ (abad), meaning to serve, to tend, to till, to work, to cultivate, or to labour. The Hebrew עָברד is used at least 288 times including 23 times in Genesis alone in the Hebrew Bible in myriads of contexts. For instance, in Genesis 2:5, עָבֵד is used in the context of cultivation of

${ }^{2}$ See $§ 2.2$ 
the ground; in Genesis 3:23: עָבָד is used in the context of tilling the ground having sent the couple away from the Garden of Eden; in Genesis 4:2,12, עָבָד is used in the context of tilling the ground (agrarian context); but in Genesis 14:4;15:13,14, עָברד it is used in the context of serving or slavery. This is why the determination of the context in which the Qal עָבָד is used in Genesis is very important in the sense that it will help to know the exact meaning and what it can imply. In a parallel reading, in 2 Kings 10:19-23, the Hebrew word עָבָבד is used in the context of worship. All five of its translations as 'worship' in II Kings 10:19-23 refers to worshippers of Baal and by implication; it could equally be called those who serve Baal in his temple (Basden, 2016).

If the word till or cultivate is used for abad in Genesis 2:15, we will also run into the problem of violence to the environment. Since the garden in God's opinion was very good (טוב [tov or tobe]) as recorded in Genesis 1:31, we can delve into an understanding that the Garden of Eden in its original form was complete for Adam and Eve's provision and also for future generations. As such, there was no need for tilling or cultivation. This understanding makes many commentators agree that the meaning of (abad) in the context of Genesis 2:15 is to serve God by keeping His commands (Grubbs, 2017). For Bridge (2013), עָבְד roughly falls into one of the metaphoric terms used for slavery in ancient Israel. By implication, Adam and Eve were to serve in caring for the Garden of Eden. If we see the Garden of Eden as complete for the first couple, then we can go with the understanding of service or stewardship in the sense that man can be seen as serving God by taking care of the Garden that was entrusted into his hands. We can, therefore translate (ָָבדד (abad) to mean 'to serve, to tend, or to dress or to care.

The second verb that conveys the message of care in Genesis 2:15 is (shamar), meaning to keep, watch, or preserve. By implication, the first couple in the Garden of Eden was given the mandate by God to protect, that is, to preserve the ecosystem to continue to remain in its original form. When the Hebrew word (shamar) is translated to mean 'keep', "it includes keeping God's commandments. As such, God's instruction to the couple to keep the Garden is a kind of command. Thus shamar seems to refer to careful keeping that watches over the object with careful observation and attention" (Basden, 2016). In Jerome Walsh's analysis of Genesis 2:4b-17, he points out that the pericope is a predominantly narrative section whose only active figure is Yahweh God and man's presence as a completely passive position (Walsh, 1977:161). By implication, when we look at the verb שֵָׁ, we can read into the text an understanding of stewardship in which God is seen as the owner and humans caretakers.

\section{An Eco-Theology for Uvwie People: The Garden of Eden Model}

The story of creation and the sustainability of the created have come under theological discussion. Here we thus adopt the Genesis tradition of God's instruction to Adam to keep the environment as a model for the construction of contextual eco-theology for Christians in Uvwie-land. What model of environmental care can we deduce from the Garden of Eden, as recorded in the text (Genesis 2:15)? Here, we give two models.

One of the models that can be deduced from the text is environmental stewardship (environmental management). From the text we understand that humans and the natural environment were created by God. Having created them, He gave humans the lead role to keep and maintain the natural environment. This therefore suggests that an appropriate environmental stewardship is required (Sherkat \& Ellison, 2007). From the text (Genesis 2:15) and even Genesis 1:26 \& 28, the word steward or stewardship was not mentioned. However, some scholars suggest that Genesis 1:28 and $2: 15$ are "the basis on which the whole discussion of stewardship ultimately rests" in the creation 
narrative (see Bauckham, 2010:11-12; see also, Habel, 2000: 46-47). Where it is indirectly mentioned in Genesis 15:2, the Hebrew masculine noun מֶׁשֶ (mesheq) is used. The Hebrew means heir, possession, or acquisition. This is why some translate כָּבָּש (kabash) in Genesis 1:28 to mean stewardship. This still does not give the understanding of stewardship, rather an understanding of dominion. This actually formed the crux of Lynn White's argument in which he accused such an interpretation as the cause of environmental destruction by humans (see White Jr., 1967:1203-1207; see also, Tirosh-Samuelson, 2021). However, the understanding of stewardship pervade the text Genesis 2:15 especially with the use of the Hebrew word (abad) and (shamar) in the context of service to God by keeping His commands and in the context of keeping God's instruction respectively. These words throw light on the understanding of stewardship. Historically, scholars trace the use of the word to ancient near Eastern cultures especially Egypt and Mesopotamia (Layton, 1990:635). Such idea could be seen in the narrative of Joseph's experience in which the title 'aser 'alhabbayit meaning someone given the duty to take care of a household for someone else was mentioned (see Layton, 1990:633-635). ${ }^{3}$ In first-century Greco-Roman New Testament world, such a person is called oikovoućw (oikonomeó) meaning steward. The steward is someone given the responsibility to take care of an estate or business on behalf of the owner for which account will be rendered when the owner comes. So the concepts of (abad) and (shamar) in Genesis 2:15 which have to do with service to God and keeping God's instruction respectively, have a link in a sense that those given the responsibility to serve in keep the Garden are responsible to God the creator. As such, environmental stewardship in this context suggests accountability, environmental responsibility, and sustainability. This gives the understanding that humans are given the responsibility to take of environment or the world given to them by God. Therefore Christians in Uvwie are challenged to be environmental stewards or managers. Christians in Uvwie and elsewhere should always be conscious of their environment with the purpose of always making it clean and green.

The second models that can be deduced from the text is environmental preservation. The Hebrew verb שֵַָׁר (shamar) in Genesis 2:15 which means to keep, watch, or preserve gives us the understanding of environmental preservation. While this text gives us this understanding, a growing controversy continues to trail the concept of texts which "frequently refer to nature as sacred, a position which classical Judaism radically opposes" (Gerstenfeld, 1999; 2001:48). This is also part of Lynn White's accusation of Judeo-Christian involvement in the destruction of the human environment especially from the viewpoint of the word "dominion" in Genesis 1:28. Irrespective of these arguments, the concept of שֵַָׁ (shamar) in Genesis 2:15 give a plain understanding of environmental preservation. Whether the environment such as forests, streams, animal species, etc have already been depleted by human activities within time and space, it still does not stop today's generation from joining the rest of the world from planting trees, breading animal species and other things that will regenerate the environment for preservation. Irrespective of the interpretations that others may have given to scriptures that negate environmental preservation is also biblical from the view point of שֶׁٍ (shamar) in Genesis 2:15. Preserving the environment (the world) and everything in it will bring about sustainability and environmental posterity safe for every creature to inhabit. This is also a biblical and theological rationale for Christians in Uvwie community to imbibe environmental care. Destruction of the environment by indiscriminate refuse disposals cannot in anyway preserve the environment.

\footnotetext{
${ }^{3}$ See Genesis 39:5; 41:40; 43:16,19; 44:1,4.
} 
In a nutshell, the message is now clear for us here in the Uvwie community. From the Garden of Eden model (GEM), particularly from the understanding of abad and shamar, Christians are to consider and understand that God created all things and made humans to become care-takers including the environment on His behalf. As such, indiscriminate dumping of refuse is not and cannot be accepted in environmental care interests. Indiscriminate dumping of refuse in Uvwie community and any community of the world for that matter makes one guilty of rebellion and wickedness. Such wickedness is not only against the environment but also against humanity in the sense that the consequences of such acts affect both the ecosystem and its inhabitants. Adam and Eve were not told to destroy the Garden in the text we have read, rather they were told to abad (tend) and shamar (preserve) it. Indiscriminate dumping of refuse on water channels or drainage cannot 'tend' or 'preserve' Uvwie's environment. As Christians in Uvwie community, God wants us and all people to be protectors of the environment from being damaged.

\section{Christians and Environmental Care among the Uvwie People}

Climate change and environmental issues were seen by some as purely scientific and technologically based. As such, they understand that such problems can only be solved through scientific means. While we agree that science and technology should be deployed to solve environmental problems, we must also know first of all that, it was this same science and technology that has been used to degrade the environment. For instance, apart from indiscriminate dumping of refuse, the activities of oil exploration in the Niger Delta area of Nigeria Uvwie inclusive is another aspect causing environmental degradation and pollution. The activity of oil exploration in this area is seriously making the people to suffer from the impact of environmental pollution and degradation. This is also an area others have stressed in previous research (e.g Jike, 2004:691-693; Eregha \& Irughe, 2009:160-166; Adekola et al, 2017:337-340) but this present paper focuses on Christians in Uvwie and how they should care for their environment. What kind of approach should Christians in Uvwie-land take to care and protect their God-given environment? Here we give four approaches. First is a good attitude towards the environment. Both Christians and non-Christians should develop a positive attitude towards the community and its environment.

Second is an admonition for all to desist from dumping refuse indiscriminately in the community and elsewhere. All must learn to use government authorized means of refuse disposal in the community. The government has an authorized dump site and an arrangement has been made by the local government as to how to dispose refuse. All should get refuse baskets or bags in their compound or area and make arrangements with those authorized to dispose those refuse. Christians should show good examples in this so that they can challenge their neighbours to do same. Third, is the involvement of individual and the Church to carry out individual and cooperate campaign against indiscriminate refuse disposal in the land. The Church has to speak against indiscriminate refuse disposal in Uvwie land. Forth is to encourage all to clear the drainage in their areas. From time to time, everyone should be involved in the clearing of the drainage to complement the efforts of government in keeping a clean and fresh environment.

\section{Conclusion}

This paper has shown from the understanding of Genesis 2:15, that (abad) and (shamar) can be translated to mean environmental caretaking/stewardship and forms a biblical/theological basis for Christians' involvement in environmental care in Uvwie community. It has also shown an indepth understanding of indiscriminate refuse disposal in Uvwie community and how Christians can contribute to preventing or tackling the menace. Moreover, it has shown that the theological 


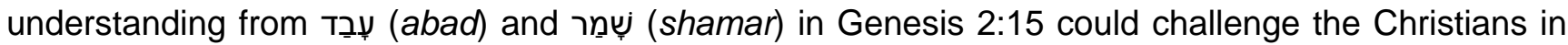
Uvwie-land to: imbibe good attitude towards the environment; develop a positive attitude towards the community and its environment; desist from dumping refuse indiscriminately in the community and elsewhere; and clear the drainages in their areas.

As such, the initiative of the Church or Christians to join in the prevention of indiscriminate dumping of refuse in Uvwie is important because, if everyone keeps mute without supporting government's initiatives of environmental sanitation, the community will be more exposed to environmental dangers. As such constant campaign against environmental degradation in Uvwie Local Government Area may go a long way to discourage Christians and sundry from dumping refuse on drainage system, roads, and unauthorized sites in the community. Although, this will impact positively on the Uviwe community, Christians from other communities can draw from this model.

Although, this paper focused on eco-theology using Christianity or the Church as an example, there is also a need for business people to also drive global sustainability by the application of a transformational eco-centric approach to business activities which prohibit polluting the God-given natural environment. This must be prescriptive in nature and thus normative because it suggests practical guidelines based on accountable ethical values. When it comes to issues such as littering, those carrying out their businesses in the market place or on the street should maintain the ethics of deposing off their refuse in a designated place like the waste basket or dump sites. By espousing ethical practices and by having ethically driven leaders, creativity and careful strategies in environmental matters, businesses big and small alike, will be able to generate wealth within legal and value-driven motivated boundaries and thus not compromise the sustainability of future generations. Nonetheless, the most indispensable tools for achieving sustainability through environmental protection are undoubtedly policy and education (Nicolaides, 2006; 2015; 2017; 2019). As such, environmental policy makers should put all including the Church, business people especially multinationals, and scientists into consideration in the road map towards sustainable clean, grean, and peaceful environment in Uvwie and Nigeria at large.

\section{References}

Adekola, O.\& Lamond, J. (2018). A media framing analysis of urban flooding in Nigeria: current narratives and implications for policy, Regional Environmental Change, 18, 1145-1159.

Adekola, J., Fischbacher-Smith, M., Fischbacher-Smith, D.\& Adekola, O. (2017). Health Risks from Environmental Degradation in the Niger Delta, Nigeria, Environment and Planning C: Politics and Space, 35(2), 334-354. DOI: 10.1177/0263774X16661720.

Aderoju, O.M., Okeke, O.J., Nwadike, B.K., Eta, J., Onuoha, H.U., Ihenacho, N.M. \& Eshiet, R. (2014). "Impacts of Urban Land use changes on flood events in Warri, Delta State Nigeria", IOSR Journal of Environmental Science, Toxicology and Food Technology,8(10), 37-45.

Basden, A. (2016). "On the Interpretation of Four Hebrew Words: Radah, Kabash, Abad, Shamar", Available online at https://kgsvr.net/xn/discussion/radah2.html (Accessed May 28, 2021). 
Basil, Eze U. \& Osheyen, S.O. (2015). The Impact of Petroleum Activities on the Socio-Economic Life of Resident Population of Uvwie Local Government Area of Delta State, Nigeria, Middle-East Journal of Scientific Research, 23(7), 1318-1320. DOI: 10.5829/idosi.mejsr.2015.23.07.9433. Bauckham, R. (2010). Bible and Ecology. London: DLT.

Bergmann, S. (2013). "Environmental Theology", in Encyclopedia of Sciences and Religions, Edited by A.L.C. Runehov \& L.Oviedo. Dordrecht: Springer. Available online at https://doi.org/10.1007/978-14020-8265-8_1539.

Bridge, E. J. (2013). The Metaphoric Use of Slave Terms in the Hebrew Bible, Bulletin for Biblical Research,23(1), 13-28.

Conradie, E. M. (2020). The Four Tasks of Christian Ecotheology: Revisiting the Current Debate, Scriptura, 119(1), 1-13.

Darragh, N. (2000). Adjusting to the Newcomer: Theology and Ecotheology, Pacifica, 13(2), 160-180. doi:10.1177/1030570X0001300204.

Deane-Drummond, C. (2008). Eco-Theology, Winona: Saint Mary's Press.

Duke, O.\& Albert, I. O. (2007). Spatial Variation and Distribution of Polycyclic Aromatic Hydrocarbons in Soil, Bulletin of the Chemical Society of Ethiopia, 21(3), 331-340.

Dyk, P. V. (2015). Responsible Stewardship-The Root of all Evil in Eco-Theology? Old Testament Essays, 28(2), 523-535. DOI: 10.17159/2312-3621/2015/V28N2A16.

Echendu, A. J. (2020). The impact of flooding on Nigeria's sustainable development goals (SDGs), Ecosystem Health and Sustainability, 6(1),1-13. DOI:10.1080/20964129.2020.1791735.

Eregha, P.B.\& Irughe, I.R. (2009). Oil Induced Environmental Degradation in the Nigeria's Niger-Delta: The Multiplier Effects. Journal of Sustainable Development in Africa, 11(4), 160-175.

Gerstenfeld, M. (2001). Jewish Environmental Studies: A New Field, Jewish Political Studies Review, $13(1 / 2), 3-62$.

Gerstenfeld, M. (1999). Neo-Paganism in the Public Square and Its Relevance to Judaism, Jewish Political Studies Review, 11 (3-4), 11-38.

Grubbs, D.(2017). Stewardship of The Land", in Sustainable Traditions. Available online at https://sustainabletraditions.com/2017/04/stewardship-of-the-land/ (Accessed May 29, 2021).

Guth, J. L., Green, J.C., Kellstedt, L.A. \& Smidt, C.E. (1995). Faith and the environment: religious beliefs and attitudes on environmental policy, American Journal of Political Science, 39:364-382.

Habel, Norman C. (2000). Geophany: The Earth Story in Genesis 1, In The Earth Story in Genesis, edited by Norman C. Habel and Shirley Wurst. EB2; Sheffield: Sheffield Academic Press, 34-38.

Heimbrock, Hans G. \& Persch, Jörg. Eds., (2021). Eco-Theology: Essays in Honour of Sigurd Bergmann. Leiden: Brill. 
Hitzhusen, G. (2019).Religion and Environmental Values in America, Columbus: Ohio State University.

Hrynkow, C. W. (2017). Greening God? Christian Ecotheology, Environmental Justice, and SocioEcological Flourishing, Environmental Justice, 10(3), 81-87. http://doi.org/10.1089/env.2017.0009.

Ikebude C.F. \& Onovughe, E.I. (2019). Physico-Chemical Characterization and Ground Water Quality Assessment in Selected Area of Uvwie Local Government in Delta State, Nigeria, Journal of Civil Engineering and Urbanism, 9(3), 17-23.

Jatto, A. A. \& Stanislas, P. (2017). Contemporary Security Challenges Facing Edo State, Nigeria, Geopolitics, History and International Relations, 9(2), 118-140.

Jike, V.T. (2004). Environmental Degradation, Social Disequilibrium, and the Dilemma of Sustainable Development in the Niger-Delta of Nigeria, Journal of Black Studies 34(5), 686-701.

Kassali, K., Girei, A.A. \&Sanu, I.D. (2018). Analysis of Yam Marketing in Akoko North-East Local Government Area of Ondo State, Nigeria, International Journal of Agricultural Marketing Research, 5(1), 170-177.

Layton, Scott C. (1990). The Steward in Ancient Israel: A Study of Hebrew ('ăšer) 'al-habbayit in Its near Eastern Setting, Journal of Biblical Literature, 109 (4), 633-649.

Mahmoud, S. H. \& Gan, T. Y. (2018). Impact of anthropogenic climate change and human activities on environment and ecosystem services in arid regions, Science of the Total Environment, 633, 1329-1344.

Nicolaides, A. \& Vettori, S. (2019).Ethical Responses and Environmental Law for Ecotourism Sustainability, African Journal of Hospitality, Tourism and Leisure, 8(2).

Nicolaides, A. (2017). Ethical Practices, Eco-centric Business and Environmental Sustainability, Journal of Human Ecology, 57(1-2), 1-10.

Nicolaides, A. (2015). Teaching Business Ethics from a Christian Social Ethics Perspective- Student Perception, Proceedings 8th Annual EuroMed Conference,16-18 September, University of Verona, Italy.

Nicolaides, A. (2006). The Implementation of Environmental Management towards Sustainable Universities and Education for Sustainable Development as an Ethical Imperative, International Journal of Sustainability in Higher Education, 7(4), 414-424.

Olajire, A. O. (2016). Vulnerability and Adaptation to Flooding: A Case Study of Uvwie Local Government Area, Delta State. Benin City: University of Benin.

Ottuh, J. A. (2018). Climate Destabilization in a Religious World: The Role of Religion in Addressing Climate Change in Nigeria, Unizik Journal of Arts and Humanities, 19(1), 69-89. http://dx.doi./org/10.4314/ujah.v19i1.4. 
Paeth, H. (2008). Human Activity and Climate Change in Africa, in Advances in Global Change Research vol. 33, edited by S. Brönnimann, J. Luterbacher T. Ewen, H. Diaz, R. Stolarski and U. Neu. Dordrecht: Springer. Available online at https://doi.org/10.1007/978-1-4020-6766-2_14.

Peterson, M. N. \& Liu, J. (2008). Impacts of religion on environmental worldviews: the Teton Valley case, Society and Natural Resources, 21, 704-718.

Pihkala, P. (2016). Rediscovery of Early Twentieth-Century Ecotheology, Open Theology, 2(1). DOI: 10.1515/opth-2016-0023.

Sherkat, D. E. \& C. G. Ellison. (2007). Structuring the religion-environment connection: identifying religious influences on environmental concern and activism, Journal for the Scientific Study of Religion, 46, 71-85.

Tirosh-Samuelson, H. (2021). Judaism and the Environment, in Oxford Bibliographies. Available online in https://www.oxfordbibliographies.com/view/document/obo-9780199840731/obo9780199840731-0118.xml. Accessed February 5, 2022.

Torretta, G. (2015). Thomas' Green Thumb, Angelicum, 92(2), 213-232.

Troster, L. (2013). What is Eco-Theology? Cross Currents, 63(4), 380-385.

Walsh, J. T. (1977). Genesis 2:4b-3:24: A Synchronic Approach, Journal of Biblical Literature, 96(2), 161-177.

Waqainabete, J. (2018). Christian Environmentalism: An Ecotheological Approach to Earth Keeping. Suva, Fiji: WWF-Pacific.

White, L. (1967). The Historical Roots of our Ecological Crisis, Science, 155 (3767), 1203-1207. DOI: 10.1126/science.155.3767.1203. 